\title{
NITRATE LEVELS AND STAGES OF GROWTH IN HYPERNODULATING MUTANTS OF LUPINUS ALBUS. II. ENZYMATIC ACTIVITY AND TRANSPORT OF N IN THE XYLEM SAP
}

\author{
Hélio Almeida Burity * ; Manuel Chamber-Perez²; Maria do Carmo Catanho Pereira de Lyra ${ }^{3}$, \\ Márcia do Vale Barreto Figueiredo ${ }^{4}$
}

${ }^{1}$ EMBRAPA/IPA, Recife, PE, Brasil, ${ }^{2}$ Centro de Investigación y Desarrollo Agrario, Apdo Oficial, Alcalá del Rio, Sevilla, Spain, ${ }^{3}$ FACEPE/IPA, Recife, PE, Brasil, ${ }^{4}$ EPEAL, Bebedouro, Maceió, AL, Brasil.

\begin{abstract}
The enzymatic study and transport of $\mathrm{N}$ in the xylem sap was carried out with a view to observing the influence of different nitrate levels and growth stages of the plant in chemically treated mutants of Lupinus albus. Several stresses induce a reduction in plant growth, resulting in the accumulation of free amino acids, amides or ureides, not only in the shoot, but also in the roots and nodules. Although enzyme activity is decisive in avoiding products that inhibit nitrogenase by ammonium, little is known about the mechanism by which the xylem carries these products. However, this process may be the key to the function of avoiding the accumulation of amino acids in the cells of infected nodules. The behaviour of the enzymes nitrate reductase (NR), phosphoenolpyruvate carboxylase (PEPC), glutamine synthetase (GS) and nitrogen compounds derived from fixation, such as $\mathrm{N}-\alpha$-amino, $\mathrm{N}$-ureides and $\mathrm{N}$-amide in mutant genotypes were observed. The NR enzyme activity was highly influenced by the application of nitrate showing much higher values than those in the non-application of nitrate, independently of genotype, being that the NR, the best evaluation period was in the tenth week. The L-62 genotype characterized with nitrate- resistance, clearly showed that the enzyme PEPC is inhibited by presence of nitrate. The L-135 genotype (nod fix') showed GS activity extremely low, thus demonstrating that GS is an enzyme highly correlated with fixation. With regard to the best growth stage for GS, Lupinus albus should be evaluated in the seventh week.
\end{abstract}

Key words: nitrate reductase, phosphoenolpyruvate carboxylase, glutamine synthetase, $\mathrm{N}-\alpha$-amino, N-ureide, N-amide, Bradyrhizobium (Lupinus), nodule cytosol.

\section{INTRODUCTION}

Stresses inducing reduction in plant growth result in the accumulation of free amino acids, amides or shoot, root and nodule ureides which may be responsible for the regulation of nodulation and nitrogenase activity through a system of regeneration (19). The same author reports that the ammonium produced by nitrogenase in symbiosis with legumes is exchanged inside the cytosol of the host cell, where

\footnotetext{
* Corresponding author. Mailing address: EMBRAPA/IPA, Av. Gal. San Martin, 1371, CEP 50761-000, Recife, PE, Brasil, E-mail: burity@ipa.br
} 
it is incorporated as amino acids and amides. It is for this reason that GS/GOGAT enzyme activity is decisive in avoiding inhibitive products from nitrogenase by ammonium. Although no information is available as to the mechanism by which the xilema carries amides or ureides, this process may be the key to the function of avoiding the accumulation of amino acids in cells of infected nodules.

On studying the reduction of nitrate in Rhizobium $s p$., Serrano and Chamber (20) observed that this includes disassimilatory and defective processes, besides the assimilatory reduction. AlcantarGonzales et al. (2) reported an increase in the reduction of nitrate in stirps $\left(\mathrm{NR}^{+}\right)$nitrate reductase and that this generally occurs with a decrease in acetylene reduction activity. In bacteroids of some B. japonicum which has a high level of constitutive NR, they showed no reduction of nitrate in nodules owing to this anion not having access to the bacteroid zone (12). Silsbury et al. (22) showed that the nitrate reductase and the fixation of $\mathrm{N}_{2}$ work in a complementary way by supplying reductive sources of nitrogen in the plants, consequently exhibiting a regulatory system involving a level of soluble $\mathrm{N}$ in the plant. Temporary treatments with high nitrate inhibit the acetylene reduction activity without any relation to nitrate reductase activity in bacteroids of B. japonicum.

There is a report in which a partially nitrate reductase deficient mutant of Pisum sativum (L.) was less susceptible to the influence of nitrate application on symbiotic $\mathrm{N}_{2}$-fixation than the wild type (11). In contrast, Ryan et al. (17) reported that a nitrate reductase mutant did not show improved nodulation compared to the wild type, so these results support the suggestion that the metabolism of nitrate was involved. The results of Burity et al. (7), suggest that Lupinus mutabilis mutants have a greater capability of assimilating symbiotically fixed $\mathrm{N}$ with greates available carbohydrates supply, and the partial tolerance to nitrate demonstrated by some mutants are apparently associated with the hypernodulated phenotype. Gibson and Harper (13) showed another type of pea mutant, whose nodulation demonstrated a greater tolerance to nitrate, althought it had normal nitrate reductase. These observations indicate that the adverse effect of nitrate on nodulation and $\mathrm{N}_{2}$ fixation can be overcome by other mechanisms, such as limited carbon supply to the nodule or cultivars with altered nitrate metabolism associated with hypernodulated characteristics.
Concerning PEP carboxilase, Vance and Heichel (28) propose that the reductive fermentative path in the cytosol of nodules involves its synthesis and that this enzyme is also inhibited by the nitrate. Streeter (25) noted the possibility that nitrate reductase activity may increase GS, and it is already known that glutamine absorbed by bacteroids controls nitrogenase activity. According to Milic et al (16), studying the symbiosis of soybean with Bradyrhizobium japonicum, the activity of glutamine synthetase (GS) enzyme in the plants is correlated with nitrogen fixation in relation to the different varieties studied.

With respect to ureides, according to Atkins et al. (3), they are formed by the oxidation of purine xantina and hipoxantina bases which return with derivatives for a new synthesis of purine nucleotids. The application of alopurinol (AP) which has a similar structure to hipoxantina, in nodulating roots result in rapid inhibition of the activity of xantina hidrogenase (XDH) in the nodules. When the isolated bacteroids of inhibited nodules show nitrogenase activity rates with small differences in relation to the control, the direct application of AP (or xantina) on the isolated bacteroids had no effect (4). These data indicate that the effect of the AP on the nitrogenase was indirect, and a consequence of the interference of certain processes essential for the functioning of the nitrogenase, more localized on the outside of the bacteroid. In this same work it was observed that the production of $\mathrm{H}_{2}$ was inhibited after 1 or 2 hours, whilst the accumulation of purines and inhibition of the synthesis of ureides in the nodules was detected after 1 hour. There are several paths by which the synthesis of ureides and nitrogenase can interact. The primary paths are intermediate (purines and ureides) which serve to regulate or aid the respiratory reactions that support the nitrogenase, and the second possibility is that respiratory substrates used by the bacteroids depend on ureide synthesis for their formation. From the disappearance of the relation between the abundance of ureides and nitrogen fixation which corresponds to the beginning of the formation of grains and the remobilization of these compounds at maturity in early genotypes, according to Aveline et al. (1), it was suggested that the interference of ureide synthesis derived from other products during senescence or even the release of these composites from any source group can quite clearly explain the lack of correlation with later genotypes. Furthermore, research into the 
measurement concerning the origin of ureides in different growth stages should be carried out.

The aim of the present work was to observe enzymatic activity and the transport of $\mathrm{N}$ in the xylem sap in the growth of Lupinus albus cv. Multolupa (standard), of two hypernodulating mutants and (L280 and L-88), one resistant to nitrate (L-62) and one inefficient mutant (L-135) inoculated with Bradyrhizobium sp (Lupinus).

\section{MATERIALS AND METHODS}

The Lupinus albus plant material was used, and according to previous work done by C.I.D.A., Centro de Investigación y Desarrollo Agrario, Sevilla - Spain the main characteristics of the cv. Multolupa mutants that was used in the study were: L-280 nod ${ }^{+} \mathrm{fix}^{+}$; L88 nod $^{+}$fix $^{+}$; L-62 nod ${ }^{-}$with resistent to $\mathrm{NO}_{3}{ }^{-}$and L135 inefficient (nod fix'). The planting methodology, procedure and statistical guidelines are cited in Burity et al. (part I).

The number and fresh weight of nodules were determined and $1.5 \mathrm{~g}$ of the nodules from each treatment were homogenized under $\mathrm{N}_{2}$ stream at $4^{\circ} \mathrm{C}$ in a phosphate buffer (24). The homogenate solution was passed though a cheese-cloth layer and the suspension was collected in tubes which were then centrifuged at $200 \mathrm{~g}$ for $20 \mathrm{~min}$. The supernatants obtained were centrifuged at $8.000 \mathrm{~g}$ for $20 \mathrm{~min}$. at $4^{\circ} \mathrm{C}$ to separate bacteroids from cytosol. Soluble protein was measured according to Goa (14), and samples of cytosol suspension were analyzed for nodule glutamine synthetase (GS) (EC 6.3.1.2) and phosphoenolpyruvate carboxilase (PEPC) (EC 4.1.1.31) activities. Nodule GS activity was determined using the ADT- transferase reaction that measures the formation of $\gamma$-glutamylhidroxamate (21), while nodule PEPC activity was determined according to the method described by Briand et al. (6). The nitrate reductase (NR) activity in the cytosol nodule was assayed spectrophotometrically $(540 \mathrm{~nm})$ according to Sanchez and Heldt (18).

The determination of nitrogen compounds in the sap derived from fixation were: $\mathrm{N}$-ureides - alantoic acid and alantoin estimated by glyoxylate hydrolysis (29); $N$ - $\alpha$-amino using the modified method descibed by Matheson et al (15), and the reagent hydridantine was prepared in accordance with Connel et al. (10) and $\mathrm{N}$-amide measured through the glutamine (26), in which the amide was estimated after hydrolysis.

\section{RESULTS AND DISCUSSION}

On analysing Table 1, significant differences can be observed, in both the nitrate levels applied and the evaluation periods, the highest rates of activity being in accordance with the mean among genotypes of nitrate reductase (NR) at the level of $5 \mathrm{mM}$ of 9.04 $\mu$ moles of $\mathrm{NO}_{3} \cdot \mathrm{h}^{-1}$. mg. ${ }^{-1}$ protein., that is almost double that of treatment not applied with nitrate. Despite there being no differences among genotypes, the L-135 obtained the activity of 11.17 , the highest in relation to the other genotypes.

The phosphoenolpyruvate carboxilase (PEPC) (Table 2), did not show significant differences, neither for 0 to $5 \mathrm{mM}$ nitrate concentrations nor for 7

Table 1 - Effect of nitrate levels and growth stage on nitrate reductase activity (NR) ( $\mu$ moles $\mathrm{NO}_{3} \cdot \mathrm{h}^{-1} \cdot \mathrm{mg}^{-1}$.protein) in five genotypes of Lupinus albus, a control genotype (Multolupa), two hypernodulating (L-88; L-280); one nitrate resistant (L-62) and one inefficient genotype (L-135).

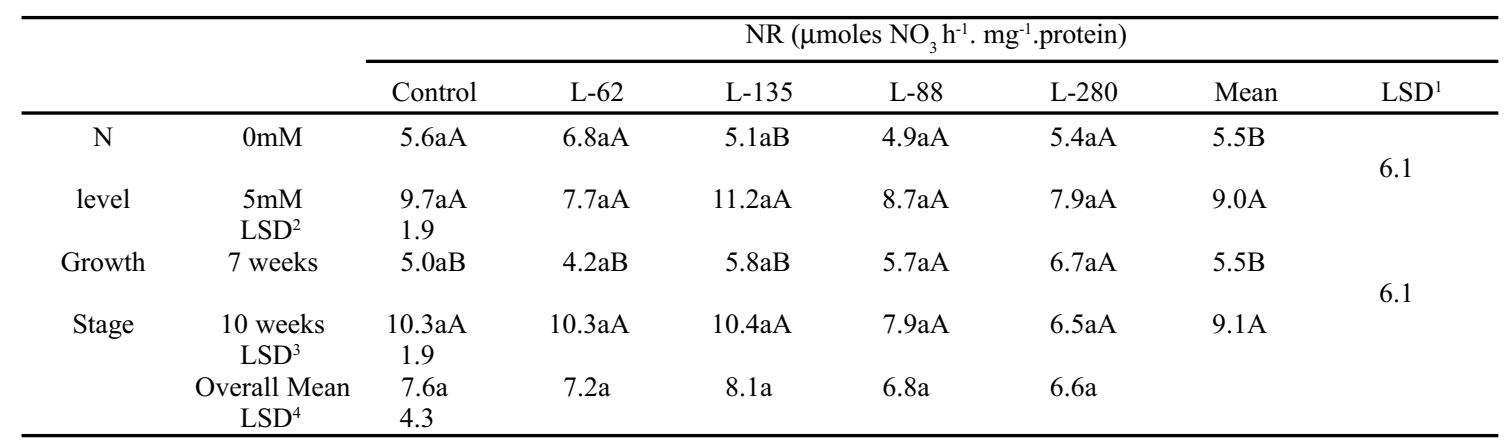

\footnotetext{
1 - LSD (0.05), between N levels and Growth Stages, averaged across Lupinus genotypes.

2 - LSD (0.05), between two N levels, within a Lupinus genotype.

3 - LSD (0.05), between two Growth Stages within a Lupinus genotype.

${ }^{4}$ - LSD (0.05), between Lupinus genotypes, averaged across N levels and growth stages.
} 
Table 2 - Effect of nitrate levels and growth stage on phosphoenolpyruvate carboxylase (PEPC) ( $\mu$ moles de PEPC. $\mathrm{h}^{-1} \cdot \mathrm{mg}^{-1}$. protein) and glutamine synthetase (GS) ( $\mu$ moles GH. $\mathrm{h}^{-1} \cdot \mathrm{mg}^{-1}$. protein) activities in five genotypes of Lupinus albus, a control genotype (Multolupa), two hypernodulating (L-88; L-280); one nitrate resistant (L-62) and one inefficient genotype (L-135).

\begin{tabular}{|c|c|c|c|c|c|c|c|c|c|c|c|c|c|c|c|}
\hline & \multicolumn{2}{|c|}{ Control } & \multicolumn{2}{|c|}{ L-62 } & \multicolumn{2}{|c|}{ L-135 } & \multicolumn{2}{|c|}{ L-88 } & \multicolumn{2}{|c|}{ L-280 } & \multicolumn{2}{|c|}{ Mean } & \multicolumn{2}{|c|}{$\mathrm{LSD}^{1}$} \\
\hline & & PEPC & GS & PEPC & GS & PEPC & GS & PEPC & GS & PEPC & GS & PEPC & GS & PEPC & GS \\
\hline $\mathrm{N}$ & $0 \mathrm{mM}$ & $25.1 \mathrm{aA}$ & $2.3 \mathrm{aA}$ & $25.5 \mathrm{aA}$ & $5.5 \mathrm{aA}$ & $18.8 \mathrm{aA}$ & $3.7 \mathrm{aA}$ & $22.3 \mathrm{aA}$ & $5.6 \mathrm{aA}$ & $14.4 \mathrm{aA}$ & $2.8 \mathrm{aA}$ & $21.2 \mathrm{~A}$ & $4.0 \mathrm{~A}$ & & \\
\hline level & $\begin{array}{l}5 \mathrm{Mm}^{2} \\
\mathrm{LSD}^{2}\end{array}$ & $\begin{array}{c}41.4 \mathrm{aA} \\
8.1\end{array}$ & $\begin{array}{c}4.5 \mathrm{aA} \\
1.17\end{array}$ & $15.6 \mathrm{bA}$ & $4.8 \mathrm{aA}$ & $20.5 \mathrm{abA}$ & $0.3 \mathrm{bB}$ & $29.1 \mathrm{abA}$ & 2.6abB & $19.0 \mathrm{abA}$ & $2.0 \mathrm{abA}$ & $25.1 \mathrm{~A}$ & $2.8 \mathrm{~A}$ & & \\
\hline Growth & 7 weeks & $45.7 \mathrm{aA}$ & $3.9 \mathrm{bcA}$ & $12.8 \mathrm{bA}$ & $8.8 \mathrm{aA}$ & $16.6 \mathrm{bA}$ & $3.2 \mathrm{cA}$ & 22.7abA & 7.2abA & $19.8 \mathrm{bA}$ & $\begin{array}{c}3.9 \mathrm{bcA} \\
0.9 \mathrm{aB}\end{array}$ & $23.5 \mathrm{~A}$ & $5.4 \mathrm{~A}$ & 25.6 & 3.7 \\
\hline Stage & $\begin{array}{l}10 \text { weeks } \\
\text { LSD }^{3}\end{array}$ & $\begin{array}{c}20.8 \mathrm{aB} \\
8.1\end{array}$ & $\begin{array}{c}2.9 \mathrm{aA} \\
1.2\end{array}$ & $28.3 \mathrm{aA}$ & $1.6 \mathrm{aB}$ & $22.6 \mathrm{aA}$ & $0.9 \mathrm{aA}$ & $28.7 \mathrm{aA}$ & $1.1 \mathrm{aB}$ & $13.6 \mathrm{aA}$ & & $22.8 \mathrm{~A}$ & $1.5 \mathrm{~B}$ & & \\
\hline & $\begin{array}{l}\text { verall Mean } \\
\text { LSD }^{4}\end{array}$ & 18.1 & 2.6 & $33.3 \mathrm{a}$ & $3.4 \mathrm{ab}$ & $20.5 \mathrm{a}$ & $5.16 \mathrm{a}$ & $19.6 \mathrm{a}$ & $2.0 \mathrm{~b}$ & $25.7 \mathrm{a}$ & 4.1ab & $16.7 \mathrm{a}$ & $2.4 \mathrm{~b}$ & & \\
\hline
\end{tabular}

1 - LSD (0.05), between N levels and Growth Stages, averaged across Lupinus genotypes.

2 - LSD (0.05), between two N levels, within a Lupinus genotype.

3 - LSD (0.05), between two Growth Stages within a Lupinus genotype.

4 - LSD (0.05), between Lupinus genotypes, averaged across N levels and growth stages.

and 10 weeks. With regard to differences among genotypes at the $5 \mathrm{mM}$ level, we note that the control treatment obtained the greatest activity of the PEPC enzyme, of $41.40 \mu$ moles of PEPC. $\mathrm{h}^{-1} . \mathrm{mg}^{-1}$ protein, whilst the L-62, a nitrate-resistant genotype, showed the lowest value $(15.55 \mu$ moles $)$. When nitrate was not applied, the activity of PEPC did not differ among genotypes. The behaviour of the L-62, which without receiving nitrate showed the highest activity of PEPC, corroborates results obtained by Vance and Heichel (28) and also resemble those of Vance and Stade (27), who observed that the nitrate inhibits the PEPC and reduces the formation of proteins (23).

Table 2 shows data for the activity of glutamine synthetase (GS) and shows that there were no significant differences with respect to the mean among the nitrate levels, although within the genotypes at the $5 \mathrm{mM}$ level, the genotypes differed in relation to the activity of GS, where the control (Multolupa), together with the L-62 showed values of 4.49 and $4.79 \mu$ moles GS. ${ }^{-1}$.mg. ${ }^{-1}$.protein. The L-135 genotype, with inefficient characteristics, obtained the extremely low value of 0.34 . For the growth stages, the difference among means in relation to the first period of 7 weeks and in relation to the second of 10 weeks was $265 \%$, suggesting 7 weeks as the ideal period for the determination of GS in this culture. Among the genotypes, the L-62 was the one which obtained the highest value, not differing from the L-88, a hypernodulator, for the first period. Streeter (25) considers the possibility of the NR increasing the GS, however, in the present work, this did not occur, given that the genotypes showing the highest values of GS in the evaluated period of 7 weeks, were not outstanding in relation to the concentration of NR, nor did they differ among themselves. Another example of differential behaviour was observed in relation to the determination of NR in these genotypes, where the best period was 10 weeks, that is, later on.

The parameters $\mathrm{N}-\alpha$-amino, $\mathrm{N}$-ureides and $\mathrm{N}$ amide (Table 3) were studied over only one cycle, the first two having been evaluated in the seventh week, the last in the tenth week. For the mean values of $\mathrm{N}-\alpha$-amino, there were no differences among the levels of nitrate applied, this behaviour being repeated for the other nitrogen compounds from the sap derived from fixation. Only in the case of Nureide levels did the L-135 genotype obtain a high value when nitrate was not applied compared to the value reached at the $5 \mathrm{mM}$ level. This behaviour is logical since the L-135, being inefficient, shows that the nitrate clearly interferes in fixation because, despite its inefficiency, the concentration of Nureides was $84 \%$ higher when nitrate was not applied. As there are innumerable paths by which the synthesis of ureides and nitrogenase can interact, according to the reports of Atkins et al. (5), this behaviour may be a form of interaction in relation to the intermediate paths which aid the respiratory reactions that support nitrogenase or the respiratory substrates that the bacteroids use to synthesise ureides. Or, as Aveline et al. (1) observed on studying the best method for evaluating N-ureides in soybean, that there is a need to investigate different growth stages of the plant in order to quantify the ureides 
Table 3: Effect of nitrate levels and growth stage on the concentrations, $\mathrm{N}-\alpha$-amino and ureide- $\mathrm{N}$ at first cylcle and amide- $\mathrm{N}$ at second cycle in five genotypes of Lupinus albus, a control genotype (Multolupa), two hypernodulating (L-88; L-280); one nitrate resistant (L-62) and one inefficient genotype (L-135).

\begin{tabular}{|c|c|c|c|c|c|c|}
\hline \multirow[t]{2}{*}{$\mathrm{NO}_{3}^{-}$Levels } & \multicolumn{6}{|c|}{ Genotypes } \\
\hline & Control & L62 & L135 & L88 & L280 & $\operatorname{Mean}_{\mathrm{N}}$ \\
\hline \multicolumn{7}{|c|}{$N-\alpha$-amino $(\mu$ moles $N / 100 \mu l$ of exuded sap) (7 weeks) } \\
\hline 0 & $348.6 \mathrm{aA}$ & $275.1 \mathrm{aA}$ & $672.8 \mathrm{aA}$ & $472.6 \mathrm{aA}$ & $804.6 \mathrm{aA}$ & 514.7A \\
\hline 5 & $639.0 \mathrm{aA}$ & $112.2 \mathrm{aA}$ & $195.5 \mathrm{bA}$ & $433.2 \mathrm{aA}$ & $502.8 \mathrm{aA}$ & 376.5A \\
\hline $\operatorname{Mean}_{\mathrm{G}}$ & 493.8ab & $193.7 b$ & 434.2ab & 452.9ab & $653.7 \mathrm{a}$ & \\
\hline \multicolumn{7}{|c|}{ N-ureide ( $\mu$ moles $N / 100 \mu$ l of exuded sap) (7 weeks) } \\
\hline 0 & $255.7 \mathrm{aA}$ & $140.7 \mathrm{aA}$ & $304.9 \mathrm{aA}$ & $160.3 \mathrm{aA}$ & $209.7 \mathrm{aA}$ & 214.3A \\
\hline 5 & $169.6 \mathrm{aA}$ & $174.4 \mathrm{aA}$ & $165.0 \mathrm{aB}$ & $172.9 \mathrm{aA}$ & $186.4 \mathrm{aA}$ & 173.6A \\
\hline Mean $_{G}$ & 212.6a & 157.5a & 235.0a & $166.6 \mathrm{a}$ & 198.0a & \\
\hline \multicolumn{7}{|c|}{$N$-amide ( $\mu$ moles $N / 100 \mu$ l of exuded sap) ( 10 weeks) } \\
\hline 0 & $20.7 \mathrm{ab}$ & $13.2 \mathrm{~b}$ & $26.5 \mathrm{a}$ & $17.1 \mathrm{~b}$ & $21.2 \mathrm{ab}$ & 19.7A \\
\hline 5 & $18.5 \mathrm{a}$ & $18.0 \mathrm{a}$ & $24.9 \mathrm{a}$ & $21.7 \mathrm{a}$ & $25.4 \mathrm{a}$ & 21.7A \\
\hline $\operatorname{Mean}_{\mathrm{G}}$ & 19.6ab & $15.6 \mathrm{~b}$ & $25.7 \mathbf{a}$ & 19.4ab & 23.3a & \\
\hline
\end{tabular}

Mean $_{\mathrm{G}}=$ Means between genotypes; Mean $_{\mathrm{N}}=$ Means between nitrate levels

$\mathrm{N}$ - $\alpha$-amino - LSD $(\%)_{\text {nitrate }}=180.3767 ;$ LSD $(\%)_{\text {genotype }}=408.1235$

Ureide-N - LSD (\%) $)_{\text {nitrate }}=55.7239 ;$ LSD (\%) genotypes $=126.0819$.

Amide-N - LSD (\%) $)_{\text {nitrate }}=2.9020 ;$ LSD (\%) genotypes $_{\text {genotypes }}^{=}=6.4891$

derived from fixation.

For the $\mathrm{N}$-amide data, the tenth week evaluation showed significant differences among the averages of the genotypes where the L-135 obtained the highest value of $25.73 \mu$ moles $/ 100 \mu$ l of sap extracted. In contrast, $\mathrm{N}$-ureides show similar behaviour to those obtained with this genotype, not differing statistically, however, from the L-280 genotype, whilst the L-62 showed the lowest value.

From these results it can be concluded that the nitrate reductase enzyme was highly influenced by the application of nitrate, showing much higher values in relation to the non-application of nitrate, irrespective of genotype, and that for NR, the best evaluation period was in the tenth week. Concerning PEPC, the nitrate-resistant L-62 genotype clearly demonstrated that this enzyme is inhibited by the presence of nitrate. With respect to GS, the L-135 genotype (nod fix $^{-}$) showed an extremely low value, thus demonstrating that the GS is an enzyme highly correlated with fixation. In relation to the best growth stage for the GS, Lupinus albus should be evaluated in the seventh week. For the nitrogen compounds derived from fixation, we suggest that a deeper study concerning the best evaluation period would be of great importance, given that each genotype demonstrates differential behaviour for the synthesis of these compounds.

\section{RESUMO}

\section{Diferentes níveis de nitrato e estágio de crescimento em mutantes hipernodulantes de Lupinus albus II. Atividade enzimática e transporte de $\mathbf{N}$ na seiva do xilema}

O estudo enzimático e o transporte de $\mathrm{N}$ na seiva do xilema foi realizado visando observar a influência de diferentes níveis de nitrato e estágios de crescimento da planta em mutantes tratadas quimicamente. Vários estresses induzem a redução no crescimento da planta da qual resulta na acumulação de aminoácidos livres, amidas ou ureídos, tanto na parte aérea como nas raízes e nódulos. A atividade de enzimas é decisiva em evitar produtos inibidores da nitrogenase pelo amônio, porém poucas são as informações deste mecanismo com o qual o xilema carrega estes produtos, em compensação, este processo, pode ser a chave da função em evitar acumulação de aminoácidos nas células dos nódulos infectados. O comportamento das enzimas nitrato redutase (NR), fosfoenolpiruvato carboxilase (PEPC), glutamina sintetase (GS) e dos compostos nitrogenados derivados da fixação como: $\mathrm{N}$ - $\alpha$-amino, $\mathrm{N}$-ureídos e $\mathrm{N}$-amida em genótipos mutados foi observado. A atividade da enzima nitrato 
redutase foi altamente inflenciada pela aplicação de nitrato apresentando valores bastante superiores em relação a não aplicação do nitrato, independentemente dos genótipos, sendo que o melhor período de avaliação foi na décima semana. O genótipo L-62, com caracteríticas de resistência ao nitrato, mostrou de forma bem evidenciada que a enzima PEPC é inibida pela presença de nitrato. $\mathrm{O}$ genótipo L-135 (nod fix $^{-}$) apresentou atividade da GS extremamente baixo, mostrando desta forma que a GS é uma enzima altamente correlacionada com a fixação. Em relação ao melhor estágio de crescimento para a GS, o Lupinus albus, deve ser avaliado na sétima semana.

Palavras-chave: nitrato redutase, fosfoenolpiruvato carboxilase, glutamina sintetase, $\mathrm{N}-\alpha$-amino, $\mathrm{N}$ ureidos, N-amida, Bradyrhizobium (Lupinus), citosol nodular.

\section{REFERENCES}

1. Aveline, A.; Crozart, Y.; Pinochet, X.; Domenach, A.M.; Cleyet Marel, J.C. Early remobilization: A possible source of error in the ureide assay method for $\mathrm{N}_{2}$-fixation mesuarement by early maturing soybean. Soil Science \& Plant Nutrition., 41: 737-751, 1995.

2. Alcantar-Gonzales, G.M.; Migianac-Maslow; Chapigny, M.L. Effect of nitrate suplly on energy activities balance and acetylene reduction and nitrate reductase activities of soybean root nodules infected with Bradyrhizobium japonicum. C.R. Acad Sci. Paris 307: 145-152, 1988.

3. Atkins, C.A.; Rainbird, R.M.; Pate, J.S. Evidence for a purine pathway of ureide synthesis in $\mathrm{N}_{2}$-fixing nodules of cowpea (Vigna unguiculata (L.) Walp). Z. Pflanzenphysiol., 97: 249260, 1980 .

4. Atkins, C.A.; Sanford, P.J.; Storer, P.J.; Pate, J.S. Inhibition of nodule functioning in cowpea by a xanthine oxidoreductase inhibitor, allopurinol. Plant Physiol., 88: 1229-1234, 1988.

5. Atkins, C.A.; Fernando, M.; Hunt, S.; Layzell, D.B. A metabolic connection between nitrogenase activity and the synthesis of ureides in nodulated soybean. Physiol. Plant., 84: 441-447, 1992.

6. Briand, J.; Calvayrac, R.; Laval Martin, D.; Farineau, J. Evolution of carboxylating enzymes involved in paranylon synthesis (Phosphoenolpyruvate carboxylase and carboxykinase) in heterotrophically grown Euglena gracilis Planta., 151:168-175, 1981.

7. Burity, H.A.; Chamber-Perez, M.; Lira Junior, M. de A.; Figueiredo, M.V.B.; Lyra, M. do C.C.P. Effects of nitrate on nodulation and $\mathrm{N}_{2}$-fixation of Lupinus mutabilis mutants at different growth stages. Rev. Microbiol., 27: 92-99, 1996.

8. Chamber-Perez, M.A.; Serrano, A. C-N balance nitrate and nitrite reductases in Bradyrhizobium sp. (Lupinus) nodules exposed to nitrate, and the relationships to nitrogenase activities. J.Plant Physiol., 139: 70-75, 1991.

9. Cho, M-J; Harper, J.E. Effect of localized nitrate application on isoflavonoid concentration and nodulation in split-root systems of wild-type and nodulation soybean plants. Plant Physiol., 95:1106-1112, 1991.
10. Connel, J.E. et. al. Quantitative chromatografic methods fase in the study of enzyme transpeptidation reactions. Canadian J. Biochem., 33: 416-427, 1955.

11. Frenstra, W.J.E.; Jacobsen, E.; Van Sway, A.C.P.M.; de Visser, A.J.C. Effect of nitrate on acetylene reduction in a nitrate reductase deficient mutant of pea (Pisum sativum L.) $Z$. Pflanzenphysiol., 105: 471-474, 1982.

12. Giannakis, C.; Nicholas, D.J.D.; Wallace, W. Utilization of nitrate by bacteroids of Bradyrhizobium japonicum in the soybean root nodule. Planta., 174: 51-58, 1988.

13. Gibson, A.H.; Harper, J.E. Nitrate effects on nodulation of soybean by Rhizobium japonicum Crop. Sci., 25: 497-501, 1985.

14. Goa, J. 1953 Scand. J. Clim. Lab. Invest. 5:218. In: Methods for evaluating biological nitrogen fixation. Chapt. 2, Mensurement of nitrogen by direct means. 1980. Ed. F. J. Bergersen, 1980, p. 65-110.

15. Matheson, A.T. et al. Quantitative chromatografic methods. An improved ninhydrin-hydridantini reagent. Canadian $J$. Biochem., 39: 417-525, 1961.

16. Milic, V.; Mrkovacki, N.; Popovic, M. Activity of nitrogen assimilation enzymes in soybean plants inoculated with Bradyrhizobium japonicum strains. Acta Microbiologica et Imunologica Hungarica., 43:135-141, 1996.

17. Ryan, S.A.; Nelson, R.S.; Harper, J.E. Soybean mutants lacking constituve nitrate reductase activity. II. Nitrogen assimilation, chlorate resistence, and inheritance. Plant Physiol., 72:510-514, 1983.

18. Sanchez, J.; Heldt, H.W. On the regulation of spinach nitrate reductase. Plant Physiol., 92: 684-689, 1990.

19. Schubert, S. Nitrogen assimilation by legumes-processes and ecological limitations Fertilizer Research (abstract) 42:99107, 1995.

20. Serrano, A.; Chamber, M. Nitrate reduction in Bradyrhizobium sp (Lupinus) strains and its effects on their symbiosis with Lupinus luteus. J. Plant Physiol., 136: 240246, 1990.

21. Shapiro, B.M.; Stadtman, E.R. Glutamine synthetase (Escherichia coli) Methods Enzymol., 17: 910-931, 1970.

22. Silsbury, J.H.; Catchpoole, D.W.; Wallace, W. Effects of nitrate and ammonium on nitrogenase $\left(\mathrm{C}_{2} \mathrm{H}_{2}\right.$ reduction) activity of swards of subterranean clover, Trifolium subterraneum L. Aust. J. Plant Physiol., 13:257-273,1986.

23. Skrdleta, V.; Gaudinova, A.; Nemcova, M.; Lisa, L. Behavior of nodulated Pisum sativum L. under short-term nitrate stress conditions. Biol. Plant., 26: 364, 1984

24. Stephens, B.D.; Neyra, C.A. Nitrate and nitrite reduction in relation to nitrogenase activity in soybean nodules and Bradyrhizobium japonicum bacteroids. Plant Physiol., 71: 731-735.

25. Streeter, J. Inhibition of legume nodule formation and $\mathrm{N}_{2}$ fixation by nitrate. Crit. Rev. Plant Sci., 7:1-23, 1988.

26. Thomas, R.J. et. al. The effect of different inorganic sources and plant age on the composition of bleeding sap of $P$. vulgaris. New Phytol., 82:657-659, 1979.

27. Vance, C.P.; Stade, S. Alfafa root nodule carbon dioxide fixation. II. Partial purification and characterization of root nodule phosphoenol pyruvate carboxylase. Plant Physiol., 75:261, 1984.

28. Vance, C.P.; Heicheil, G.H. Carbon in $\mathrm{N}_{2}$-fixation: limitation or exquisite adaptation. Annu. Rev. Plant Physiol., 42: 373392,1991

29. Vogels, G.D.; Van der Driff, V. Differential analysis of glyoxylate derivates. Anal. Biochem., 33: 143-157, 1970. 